\title{
CASEY GURFINKEL
}

$S$

Supervisor: Prof. Ruth Panofsky

Second Reader: Prof. Joy Cohnstaedt

The Major Research Paper is submitted in partial fulfillment of the requirements for the degree of Master of Arts

Joint Graduate Programme in Communication \& Culture

Ryerson University - York University

Toronto, Ontario, Canada

December 2006 


\section{Table of Contents}

Introduction

Chapter One: ECW Press and Jack David

Chapter Two: McClelland \&Stewart and Doug Gibson

31

Chapter Three: Random House / Knopf Canada and Michael Schellenberg

Conclusion

Appendix A

Works Cited 


\section{Introduction}

Since the merger of Indigo and Chapters in 2001, and the bankruptcy of Stoddart Publishing and General Distribution Services in 2002, the Canadian publishing industry has faced perilous times in an already troubled market sector. In addition to the problems specific to the Canadian publishing industry - for example, federal and provincial funding cuts to the industry; the monopoly of the book retail market by the chain outlet Chapters-Indigo; the difficulty and expense of book distribution within Canada; competition from multinational publishing companies; the lack and expense of traditional marketing opportunities - the growing global market for books presents further difficulties for an industry that is struggling to retain its "Canadian" focus. This study considers the recent impact, both positive and negative, of globalization on the Canadian book industry, with a specific focus on publishers as the key figures in this industry. By surveying three publishing houses that represent specific segments of the industry - large multinational, mid-size, and small presses - I examine different approaches to surviving in the current book market and offer several conclusions about the future of Canadian publishing, most notably that the larger the publishing house, the less it is troubled by challenging market conditions.

Since the available secondary literature on the Canadian publishing industry is sparse and my focus is contemporary, this paper relies extensively on primary research. Interviews with three publishers - or their representatives form the basis of the case studies presented here: president Jack David of ECW Press; one-time president Douglas Gibson of McClelland \& Stewart; and senior 
editor Michael Schellenberg of Knopf Canada, an imprint of Random House Canada. Despite differences in size and publishing programs, ECW Press, McClelland \& Stewart, and Random House serve as valuable case studies for this project which reveals surprisingly similar perspectives across the three publishing companies.

All three of the companies under consideration here are located in Toronto, Ontario, Canada. While it would have been preferable to study a broad sample of publishers from across Canada, the province of Ontario is home to over 50 per cent of Canadian publishing companies, including the majority of mid-size and large publishers, and Ontario generates 71 per cent of book publishing revenue in Canada (http://www.omdc.on.ca/Page3652.aspx). For the purposes of this study, the term "Canadian book" refers to any book written by a Canadian citizen. In discussing Canadian identity in a global context, however, Canadian authorship alongside Canadian focused subject matter will be considered the ideal product for the representation of Canadian identity abroad.

Formerly a publisher specializing in poetry and critical studies aimed at the scholarly and library markets, in the interest of survival ECW Press has made significant changes to its publishing program since its inception in the 1970s. In the mid-1990s, partners Jack David and Robert Lecker began to change the academic focus of their press to more mainstream publications and started to publish American sports, music, and television star biographies. By the late 1990s, they had begun to issue travel guides. As a result of these changes "American sales grew to two-thirds of the press's volume and increased its 
revenue by 300 percent, to over $\$ 2$ million, in just three years" (MacSkimming 359).

Hailed as the most Canadian of all Canadian publishers, McClelland \& Stewart has undergone surprising twists and turns, especially since 1952 when Jack McClelland took over the business from his father. Prior to his final departure from publishing in 1987, McClelland had created the paperback reprint series New Canadian Library, nearly bankrupted the press several times, and had to be rescued financially by the Ontario government before selling his shares in the company to Avie Bennett in 1983. In June 2000, in a surprising move of his own, Bennett donated 75 per cent of M\&S to the University of Toronto, and the remaining 25 per cent to one of M\&S's largest competitors, Random House of Canada.

In light of its connection to M\&S, it is fitting to examine Random House of Canada as a representative of the large, multinational publisher in Canada. Having entered the Canadian marketplace as a distributor in 1944, Random House began its own Canadian publishing program in 1986 and today it is one of three multinational publishers - alongside HarperCollins and Penguin dominating the Canadian publishing industry. Now owned by the German conglomerate Bertelsmann, under a multitude of imprints - including Knopf Canada - Random House issues some of the largest names in Canadian publishing. Critics of Random House's partial ownership of M\&S worry, however, over the amount of control this American-owned publisher now exercises over the Canadian publishing industry. 
These representative publishing companies face similar difficulties, but with varying degrees of intensity. In what follows, I outline these difficulties with broad strokes; individual chapters will revisit each difficulty in relation to the publisher under consideration.

\section{Canadian Book Publishing Policy}

Since the early 1990s, federal and provincial funding cuts to the Canadian book industry have adversely affected most Canadian publishers. Paul Martin, then federal Minister of Finance, instituted the first funding cuts. Over a period of two years, Martin cut funding to the major federal book program, the Book Publishing Industry Development Program (BPIDP), as well as the Publications Distribution Assistance Program. In 1995, in the wake of the federal cuts, Mike Harris was elected Premier of Ontario and instituted provincial funding cuts to the Arts. Ontario Arts Council funding was cut by about 40 per cent and the Ontario Culture Centre ceased to exist.

At the federal level, through the Department of Canadian Heritage, the Book Publishing Industry Development Program (begun in 1979) was the first federal subsidy program for publishers. It began as a three-year 20 million dollar infusion of funds, with a goal of "strengthening commercial firms as they try to grow" (Lorinc http://www.quillandquire.com/features/article.cfm?article_id=2228). Currently, the BPIDP provides approximately $\$ 39$ million in annual support to the publishing industry, used mostly for production and promotion of titles. 
The Loan Program for Book Publishers, developed through Canadian Heritage and the Royal Bank, helps publishers gain or increase their access to bank financing. Similarly, the Cultural Industries Development Fund supports Canadian cultural production through term loans in conjunction with the Business Development Bank of Canada. "As well, parallel importation regulations through the Copyright Act protect agreements for the distribution of books in the Canadian market" (http://www.pch.gc.ca/progs/ac-ca/pol/livre-book/index e.cfm).

Also at the federal level, through the Canada Council for the Arts, publishers can receive monies through the Block Grant Program to offset deficits incurred from issuing literary titles. However, while this program once offset approximately 80 per cent of the operating deficit for these publications, "today, with an outlay of $\$ 6.5$ million, the program covers just $30 \%$, with the money split up among about 800 titles, for a paltry average of just $\$ 8,000$ " (Lorinc http://www.quillandquire.com/features/article.cfm?article_id=2228).

Foreign investment policy also protects the Canadian book industry in several ways. Foreign investment in new business enterprises is limited to Canadian-controlled, joint ventures. Non-Canadians cannot take over Canadiancontrolled businesses. Canadian investors must have a fair opportunity to buy a business that a non-Canadian is selling. Finally, "indirect acquisitions are reviewed to determine whether they are likely to be of net benefit to Canada and to the Canadian-controlled sector and are assessed on their merits by reference to the regulations set out in Section 20 of the Act" (http://www.pch.gc.ca/progs/ac-ca/pol/livre-book/index e.cfm). 
Recently, the federal government introduced an initiative to assist publishers experiencing persistent problems associated with inefficient distribution. The Supply Chain Initiative provides funding to the Canadian book industry for projects and activities designed to strengthen and modernize the supply chain for books in Canada. This includes "the improvement of the quality and accessibility of bibliographic data, the promotion of standards-driven electronic document interchange, and the promotion of access to data on book sales" (http://www.pch.gc.ca/progs/ac-ca/pol/livre-book/index e.cfm).

Coupled with Booknet, a private international tracking system now employed by publishers and retailers in Canada, this initiative should help alleviate distribution problems endemic to the Canadian book industry.

The province of Ontario offers book publishers a tax credit. Previously, only a first title was eligible, but as of early 2001 "the government tripled the maximum tax credit for individual titles - from $\$ 10,000$ to $\$ 30,000$ - and publishers can now apply for a tax rebate for costs associated with publishing the first three books in a writer's career" (Crawley http://www.quillandquire.com/news/article.cfm?article_id=4069). The credit can be applied to eligible works by first-time Canadian authors and is co-administered by the Ministry of Finance and the Arts and Cultural Industries Unit of the Ministry of Culture"(http://www.culture.gov.on.ca/english/culdiv/cultind/ bookpub.htm). However, due to the large expense of publishing new authors, few Ontario publishers can make maximum use of this tax credit. For the most part, 
large firms with the resources to take risks and publish new authors will benefit from the Ontario tax credit.

\section{Bookstores}

\section{Chapters-Indigo}

In 2002, the super-sized bookstore chains Chapters and Indigo merged aggravating many of the problems in the Canadian retail book market. The history of the Chapters-Indigo merger is a convoluted one, filled with twists and complications. It is most succinctly described by Roy MacSkimming in The Perilous Trade: Publishing Canada's Writers, which informs this section. In 1994, before there was either Indigo or Chapters, a Harvard Business School graduate named Larry Stevenson bought Smithbooks, formerly W.H. Smith's, and later that year he also purchased the Coles Bookstore chain. Stevenson merged the two chains and renamed the corporation Chapters. With the creation of Chapters, "publishers no longer had a significant alternative retailer in Canada; if the Chain didn't order a title, that book automatically lost access to half the domestic retail market" (MacSkimming 360). Additionally, hundreds of Canadian independent publishers "faced a single-minded, predatory foe" (MacSkimming 360).

The first Chapters superstores were opened in 1995, successfully passing through the federal Competition Bureau. Within five years, there were 71 Chapters superstores throughout the country. Following the opening of the superstores, there were other, more dangerous developments for the book industry. The first was the launch of the unprofitable Chapters Online in 1998, but 
the opening of Pegasus, Chapters's "wholesale" wing, hit the publishing industry the hardest.

While Pegasus claimed it was a "wholesaler," its actual function was "filling orders for Chapters.ca customers and supplying books to the Chain's own stores" (MacSkimming 362). As a supposed wholesaler, it could demand a high discount from publishers. "Pegasus demanded from them a wholesaler discount of 50 percent-plus, in place of the 45 to 48 percent they'd been giving Chapters" (MacSkimming 362). Even though Chapters claimed otherwise, it was understood by publishers that if they did not agree to these terms, their books would not be on sale at any Coles, Smithbooks, or Chapters locations.

Several publishers decided that they did not want to offer the additional discounts that Chapters was demanding. Firefly was one such publisher and it would serve as an example of what would happen if a publisher decided not to cooperate. "Chapters responded by returning $\$ 1$ million worth of books for credit, including titles from Annick, Owl, and the other presses distributed by Firefly" (MacSkimming 362). Firefly was not the only publisher to receive massive returns. In spite of complying with Chapters discount demands, publishers began to receive returns for credit across the board. Returns would arrive in by skids, and often the books were damaged. "Equally disturbing, publishers found the value of the returns sometimes varied wildly from the credit being claimed" (MacSkimming 363). This also resulted in many hours of lost manpower to verify the value of the returns. 


\section{Independent bookstores}

The independent bookstores of Canada have long been important cultural centres to hundreds of communities. More than just retail establishments, they have provided a welcoming atmosphere and served as the breeding ground for ideas. They are often family-run stores or, at the very least, have a sense of their history and place in the community. Many provided these communities with book clubs and were places where individuals could gather and discuss the literature of Canada and abroad. But a great number of them have had to close their doors due to competition from Chapters-Indigo. While the examples used throughout this study are in Toronto, a similar impact was felt by independents throughout Canada. One specific case is Toronto's Litchman's, a family-run business of nine decades and nine stores. When Lichtman's filed for bankruptcy in late March 2000, Judy Stoffman reported in a Toronto Star article, dated 31 March 2000 , that "The pain is too severe. You'd need a war chest of $\$ 20$ million to hold your own against Chapters, Indigo, Amazon and the dot-coms" (Stoffman 1). Litchman's was not alone. By the time it closed its doors, it had been preceded by Edward's, The Book Cellar, Writers \& Co., Britnells, Village Books, and Ulysses Travel Books, each of which cited Chapters-Indigo as one of the main motivations for closure (Stoffman 1).

\section{Distribution and the Canadian Marketplace}

Distribution has long been a significant problem specific to the Canadian marketplace. In a country that is geographically vast, with a relatively small and dispersed population, distributing books becomes extremely expensive and 
complicated. A case in point is Stoddart Publishing and General Distribution Services, its distribution arm, which had been especially vulnerable to Chapters and Pegasus; Stoddart and GDS had relied on Chapters "for up to 70 percent of its sales of new releases.... [and w]hen Chapters started playing dangerous games with credit notes and returns, GDS was directly in the line of fire" (MacSkimming 377). However, this was not the only problem that Stoddart and GDS were facing. They had recently moved into a new warehouse, four times as large as their previous location, had lost many important staff members as a result of the move, had spent 2 million dollars to replace their computer system for the millennium, and in the middle of the 1999 Christmas season, because of computer troubles, were unable to ship books for 12 days (MacSkimming 378). Soon afterward, Stoddart and GDS experienced such serious cash flow problems that the Department of Canadian Heritage approved a loan guarantee of 4.5 million dollars, with which Stoddart "paid off much of his debt to client publishers, authors, and printers, all of whom had been suffering collateral damage from his woes" (MacSkimming 378).

In spite of loans and several other attempts at refinancing, in April 2002 General Publishing, the company that held all of Stoddart's publishing interests and was 85 per cent owned by Jack Stoddart himself, filed for bankruptcy protection (MacSkimming 379). For many publisher clients of GDS, this was disastrous. They were owed hundreds of thousands of dollars by GDS and many publishers could not even take possession of their own inventory. "To help the victim bridge the cash flow gap and ready their books for the fall season, 
Canadian Heritage "provided GDS's Canadian clients with substantial advances on their regular funding" (MacSkimming 383). The federal government allowed publishers to draw several years' worth of advances from the Book Publishing Industry Development Program and the Ontario government provided 1.5 million dollars in emergency assistance. However, in spite of all the aid, several publishers did not survive the hostile economic environment and those that did were forced to seek out new and innovative strategies to keep their businesses thriving in unfavourable conditions. This same statement may also be true of Canadian writers. Unfortunately, this is beyond the scope of this project but could serve as a good subject for a future study.

The three publishing companies featured here survived the collapse of GDS and in this paper I attempt to ascertain the overall impact of that crisis. The individuals interviewed for this project were asked questions about the history and growth of their respective companies, how they have adapted to changing economic conditions, and what business strategies they employ to move forward (please see Interview Questions, Appendix A). As a result of my research, I foresee a more positive future for the Canadian publishing industry then I had originally hypothesized. Although there have been many challenges facing the industry in recent years, each of the publishers discussed here have found ways to survive and even grow in a harsh economic environment. While two of the three publishers were more threatened by economic conditions than their multinational counterpart, all three publishers believe that globalization has had a positive or neutral influence, rather than a negative impact, on the publishing 
environment. The question of what it means to remain "Canadian" in a global market, however, led to deeper questions of what is a "Canadian" book in the first place. All three publishing companies have found that remaining "Canadian" in a global market is actually becoming easier - as long as the definition of a Canadian book, a Canadian author, and, of course, a Canadian publisher remains sufficiently broad. Ultimately, survival is the chief priority of the three publishers. What is surprising, however, is the fact that their strategies for success are not dissimilar. 


\section{Chapter One: ECW Press and Jack David}

In 26 years of business, ECW Press and its co-founder Jack David have experienced every possible difficulty facing Canadian publishers. Although a small press in relation to the multinational publishers with branches in Canada, today ECW is one of the larger Canadian-owned publishers. Its books are varied in subject matter and sold worldwide in a multitude of languages. As the only 100 per cent Canadian-owned publisher that this paper examines - and one of the few still in existence - ECW Press serves as an exceptional case study to showcase the impact and results of the problems that have plagued the Canadian book industry over the last quarter century.

\section{History of ECW Press}

The boardroom of the ECW Press offices in The Beach area of Toronto serves as a visual, chronological history of the Press, as well as the state of the Canadian book industry. Mounted on several towering bookshelves, in order of publication, is every book that ECW has ever published. One's gaze is directed first to the top left shelves filled with bibliographies of Canadian writers such as Margaret Laurence, Margaret Atwood, and Michael Ondaatje; the centre, middle shelves are occupied by colourful books, among them a book on David Duchvoney and the $X$-Files, with bold Japanese text printed across the front cover; and the bottom, right shelf holds recently commissioned corporate publications. The evolution in ECW's publications over the last 25 years and the concurrent changes that have characterized the Canadian book publishing 
industry are not without historical significance. Each change in ECW's publishing program reflects a careful and strategic reaction to the range of difficulties the Press has faced in the Canadian book market.

ECW Press began in 1974 with the scholarly journal Essays on Canadian Writing or ECW. Jack David was a graduate student at York University and that particular year there was money left over in the English Graduate Student's Association fund that was returned to department. The previous year, graduate students had used that funding to have a "beer party." In 1974, however, for reasons that remain unclear - even to himself - David decided to start a magazine and he held a meeting to encourage participation from other graduate students. A few agreed to help and they began to publish Essays on Canadian Writing. "The Journal," as the magazine became known, acquired a second editor in 1975. Fellow graduate student Robert Lecker became David's partner and together they ran the journal and later the press, until David bought Lecker out in October 2003.

"As grad students we felt there was a lack of information about Canadian writers. So we felt it was part of our responsibility, our mandate, to publish information for other grad students" (David). David cites the example of a graduate student who was writing a paper on Margaret Laurence but could not locate critical material or bibliographies on the author. Since David and Lecker liked to compile information, bibliographies, essays, and interviews on different Canadian authors, they decided to create a series of bibliographies in book form. In 1977, the pair signed a contract to publish the series with a group called Peter 
Mark and Associates. As they began to receive bibliographies that were prepared by scholars and librarians, it was evident that Peter Mark and Associates were having financial trouble - they ultimately went bankrupt. David and Lecker were left with all the bibliographies but no publisher. Having issued the journal, they soon decided, however, that they knew enough about publishing to undertake publication themselves - and the result was the first publication by what is now ECW Press.

In the early 1980s David and Lecker met John Metcalf, a writer and an editor who was then being published by Oberon Press. When Metcalf expressed his unhappiness with Oberon Press, David and Lecker decided that ECW should begin to publish fiction. They began to publish Metcalf's fiction alongside the fictional works of other Canadian authors such as Hugh Hood; in 1982, however, they realized that publishing fiction was losing them a great deal of money. The decision was made to cease publishing fiction and the Press turned instead to the publication of literary criticism and reference works. These types of publications continued until the early 1990s when there was another shift in the focus of ECW due to large-scale budgetary cuts to libraries across Canada. With ECW's primary market facing increasing budget cuts, the Press started to produce books that Canadian high school students might be interested in reading. Akin to up-scale Coles Notes, this Canadian fiction study series was written by academics in straightforward language.

Shortly after broadening its market to high school readers, ECW also began broadening the subject matter of its publications. Rather than focus solely 
on Canadian writers, ECW published a book on Canadian cultural figure k.d. lang. In 1992, ECW's American distributor managed to place the book in the growing number of gay and lesbian bookstores across the United States.

Ultimately, ECW sold an unprecedented 20,000 copies of the k.d. lang book; previously, an ECW book would sell no more than 1,800 copies. This shift in sales gave ECW important insight into saleable subject matter and the potential of the U.S. book market.

Federal and provincial funding cuts to the Canadian book industry adversely affected ECW in 1995. Since both the federal and provincial cuts took effect at relatively the same time, ECW had very little time to react. Although there were points when they considered going out of business, David and Lecker decided otherwise. Applying their literary critical background to popular culture resulted in David and Lecker's first trade book on the topic of the $X$-Files, a once popular television show. Since $X$-Files was broadcast all over the world, ECW was able to sell rights to the book in many countries. The Press proceeded to research, write, edit, design, and distribute many more books like the $X$-Files book - until the bankruptcy of General Distribution Services in 2002. Subsequent to the GDS bankruptcy, ECW faced an onslaught of problems within the Canadian book market. As a result, ECW modified its publishing program several times before it became the Press that it is today. 


\section{Difficulties}

Some of the difficulties outlined in my introduction affect ECW, a small, Canadian-owned press, more significantly than the other two publishing companies under consideration here. These difficulties include competition from multinational publishers, attracting and retaining Canadian authors, and succession of ownership. More than the other difficulties already outlined in my introduction, these three difficulties have forced ECW to adopt unique strategies for success in the unsympathetic environment of Canadian publishing.

\section{Multinational Publishers}

One of the salient difficulties facing Canadian-owed publishing companies such as ECW is the presence of multinational publishers in Canada. The largest of all the Canadian-owned publishers, such as H.B. Fenn and Company, have revenues of between 8 and 10 million dollars and publish around 80 books a year. ECW falls somewhere between a large Canadian publisher and a small Canadian publisher, with a list of between 20 and 50 books a year. However, compared to one branch of the multinationals like Random House, even the largest of Canadian publishers are "small potatoes" (David). Although a profit margin of 10 per cent is considered relatively low for other industries, for publishing it is practically unattainable. In fact, most profit margins for Canadian publishers are between three and five per cent. Incredibly, a recent Publisher's Weekly article, dated 21 August 2006, stated that Penguin's margins had risen from 6.6 per cent in 2004 to 7.5 per cent in 2005 and Random House's margins 
had moved up from 7.9 per cent in 2004 to a staggering 9.1 per cent in 2005 (Milliot

http://www.publishersweekly.com/article/CA6364168.html?text=penguin+and+profit). These high profit margins are partially attained through distribution channels, including Canadian distribution. The publication of Canadian titles by multinational branches in Canada is subsidized by the more lucrative sales of authors such as Danielle Steele and John Grisham, whose mass-market novels sell millions of copies worldwide.

The multinational publisher has one goal in mind, according to David, and that is making money: "The difference on the Canadian side is that while no one is adverse to making money, the Canadian side understands that making money is the least likely possibility that we've got. What we try to do is stay in business." (David). David suggests that multiple revenue sources, grants, and low wages help keep Canadian publishers afloat.

David also notes that Canadian publishers have a hard time competing with multinationals in the arenas of printing and shipping. The large volume that multinationals print and ship lowers the unit cost of each book, raises their profit margins, and significantly improves their bottom-line. For example, once a multinational plans to print 500,000 copies of a Danielle Steele book, adding another 20,000 for the Canadian market is much easier and cheaper since the unit cost has become lower due to the large print run. In contrast, a typical print run at ECW of 3,000 books has a much higher unit cost and results in a lower profit margin for the publisher. 
Distribution of a book for the Canadian-owned sector is another substantive problem, although to some degree multinationals experience this difficulty as well. Without a centralized distribution service, freight costs in a country as geographically vast as Canada, with a dispersed population, is a huge expenditure that will be discussed at greater length in chapter two. In contrast, multinationals try to lower their shipping costs by consolidating shipments.

The Retail Book Environment: Chapters-Indigo

ECW Press was not spared the problems that developed with the rise of Chapters, Pegasus, and Indigo, especially with respect to returns. Referring to the returns as "messy," David describes a typical scenario that occurred with Chapters-Indigo: "The chain would order $\$ 1,000$ worth of books from you and you shipped them the books. You invoice them for $\$ 1,000$ and expect to be paid in 100 days or something. At about the time when they are going to pay for the order, they say they received 52 books, but not the fifty-third book. Until they figure out what is going on with that fifty-third book, they cannot pay for the order. So they can drag this out for a really long time, forcing publishers to say, okay, we give in, you win, we're not going to dispute this, take it away. So they've got all the cards. That's where they hurt you" (David).

Many believe that the major book chain is not solely a Canadian problem, but a problem facing the U.S. as well. David disagrees: "We function quite well in the U.S. system with Borders, Barnes \& Noble, your major chains, and the wholesalers, too. They order, they stock, and if you pay them money to tour your 
book, they will comply with those sorts of things. They are far, far better than Indigo, Chapters, Coles. So I think that's it's a very localized problem" (David).

The Retail Book Environment: Independents

David notes that, ten years ago, the area around Yonge and Bloor streets in Toronto used to be book territory, with at least seven bookstores, including Britnell's and The Bookseller. He can now name only several bookstores in downtown Toronto, including This Ain't the Rosedale Library, the Book City chain, and specialty stores like the Cookbook store.

Lost with these stores is their owners' and their employees' love for books, which is lacking in the Chapters-Indigo chain. Generally, for employees of Chapters-Indigo customer care is secondary to sales: "Among independents, the cultural quality of the title selection has more to do with the staff's experience and the demographics of its customer base than any other factor" (Lorinc http://www.quillandquire.com/features/article.cfm?article_id=2228). Murray Teitel of the Toronto Star summarizes the problem in an article dated 19 November 1999:

Unfortunately, however, another force has arisen that will restrict the flow of information and ideas - the domination of the Canadian book retailing business by the box store Chapters. It now accounts for almost half of the sales of books in Canada. Independent bookstores tend to be run by owners/operators who love books. Chapters is run by people who love money. Whereas traditionally booksellers sell what they like and recommend, Chapters will stock books according to a formula based on how well they have sold or are expected to sell. (Teitel 1 ) 
Herein lies the most pernicious aspect of the retail problem. With the closure of independent bookstores, Chapters-Indigo now dominates the market. Thus, their selection of books determines which books are accessible to readers. In essence, a tiny minority is deciding what all of Canada reads.

\section{Canadian Authors}

As always, the proportion of Canadian publishers to Canadian writers has never been in the writer's favour. At ECW, David receives about four or five paper manuscripts a day, as well as several online submissions, and his two acquisitions editors receive approximately the same number. In total, ECW looks at over 4,000 manuscripts a year. Despite the volume of manuscripts, according to David "there are never many good books. A good publisher is someone who has an instinct for what is good, either culturally valuable or commercially valuable. And you get lucky, and you're able to negotiate a contract. A lot of writers send their work to 10 to 15 publishers and publishers are so over burdened that 12 of them do not even get a chance to look at the submission" (David).

Once a smaller publishing house like ECW secures an author, however, the initial investment in promoting that author is high. ECW is currently sending one of its authors on a short book tour to the Calgary and Saskatoon branches of McNally Robinson Booksellers. Once they have paid for airfare, accommodation, and co-operative promotion within the two stores, a great deal of capital has been invested in the author. Since this is a first-time author, ECW knows that the 
book will not sell well. Then why go to all the trouble? They have to because when there is a second novel there will be more of a response from the public, and by the time the fourth or fifth novel is published, the author might be hit. At that point, however, a larger problem often occurs. The author could secure the services of a literary agent who will approach one of the multinationals which may offer the author a royalty advance of $\$ 20,000$, low by multinational standards. ECW can only offer a royalty advance of $\$ 3,000$ to $\$ 4,000$ because that is all the income the book will generate. Historically, small presses have smaller print runs, spend more time working with authors, and are more willing to take risks on unknown writers. This is how Margaret Atwood's career began, for example; she published poetry with House of Anansi Press before moving to McClelland \& Stewart for the publication of her first novel, The Edible Woman, in 1969.

However, trends indicate that it no longer takes until the fifth book before a large publisher becomes interested in an author's work. In fact, a small press's interest in a book now seems to be enough to spur the interest of a large press. After receiving a rejection of a 25 -page sample that she had sent to $M \& S$, for example, Nova Scotia writer Dawn Rae Downton was made an offer by Flanker Press, a small east coast publisher. When Flanker made an offer on her book Seldom, Downton informed M\&S editor Dinah Forbes as a courtesy. Downton "immediately received a counter-offer she couldn't refuse" (Yanofsky http://www.quillandquire.com/features/article.cfm?article_id=2313). That M\&S did not want to lose the book (Yanofsky 
http://www.quillandquire.com/features/article.cfm?article_id=2313) - after an earlier rejection - came as a surprise to Downton.

Royalty advances for authors from large publishers are climbing higher and higher, making it difficult for small publishers like ECW to compete for writers. Some advances are reaching the high five-figure range for a first novel, a sum that is unreasonably high for a small publisher. Susan Renouf, editor-inchief at Key Porter Books, comments, "I think that the advances are getting ridiculously high for Canada" (Lahey http://www.quillandquire.com/news/article.cfm?article_id=1183). Even higher than the five-figure advances are the six-figure advances that some authors are being paid. Hungry for new talent, literary agent Anne McDermid negotiated a $\$ 400,000$ advance with Doubleday U.S. for Wayne Johnston's novel The Colony of Unrequited Dreams - "an unprecedented amount for a lesser-known Canadian writer"(Lahey http://www.quillandquire.com/news/article.cfm?article_id=1183). Rod McQueen's book about the collapse of the Eaton empire earned him a $\$ 100,000$ advance from the now defunct Stoddart publishing - perhaps an indication of where such high advances may lead. Roy MacSkimming cites the rising advances as a major problem in the industry, suggesting that government measures should be taken to help alleviate the problem: "By supplementing advances, such a program would enhance publishers' ability to retain their authors and would simultaneously benefit writers" (MacSkimming 391).

Stranger still is the fact that these uncharacteristically large advances are now being given to many first-time authors. In Anita Lahey's 1998 article 
"Advances Climbing in Heated Market," Doubleday editor John Pearce is quoted as saying that it is highly unusual for a first-time author's advance to rise above $\$ 15,000$ : "For the author to be more than $\$ 15,000$ it would have to be something utterly exceptional, or come with built-in promotion, meaning the author's famous in some other way, and has a built in audience we didn't have to create" (Lahey http://www.quillandquire.com/features/article.cfm?article_id=2313). Only three years later, in 2001, "first fictions" were not only being published by large publishers, but there was an upward trend in advances, with authors normally receiving between $\$ 15,000$ and $\$ 25,000$. Literary agent Denise Bukowski explains: "As one might expect, advances have increased over the years, but in the same year [2001] I've done contract rights for $\$ 10,000$ and $\$ 70,000$ for a first novel, for Canadian rights. Most of them now get $\$ 15,000$ to $\$ 25,000$ for Canadian rights"' (Yanofsky http://www.quillandquire.com/features/article.cfm?article_id=2313). These are high advances that ECW and other Canadian publishers of the same size cannot possibly afford to offer.

\section{Succession}

Since many of the publishing companies in the Canadian-owned sector were founded in the 1970s, in the next five to ten years their publishers/owners will be reaching retirement age. This presents a major issue for these companies. However, for a cultural organization that David compares to the National Ballet or the Toronto Symphony Orchestra, with a history, legacy, and backlist of its own, 
a buyer from outside of the organization may not be appropriate. While the publishing industry is not a "not-for-profit" organization, it is an organization where the bottom-line is not always the primary concern. Rather than an outside buyer, publishers like ECW are looking for internal buyers who are involved in the industry, committed to books, and know that money is not necessarily the most important component of the business.

In the case of ECW, David has developed a core group of people to take over the Press in the next five to ten years; they "recognize the hazards of being in business and they are still saying yes, for the next twenty years of my life I am willing to pursue this" (David). The hope is that the federal government will subsidize the takeover in the form of low interest loans that can be used to buy out the current owner, and pay the government back over time. This way, employees who are currently working two jobs to support themselves - which is the case with several employees at ECW - could have the means to purchase the company.

\section{Strategic Initiatives}

In response to the problems specific to ECW Press, and the over-arching challenges facing Canadian publishing, Jack David has adopted several core strategies that have allowed him to remain in business and in the black - not an easy task for a Canadian publisher. 


\section{Alternate Markets}

Given the plenitude of English language books published in Canada and imported from abroad, as well as the monopoly of Chapters-Indigo over the book retail market, ECW has turned to alternative markets as additional sources of revenue. ECW seeks specialty markets, such as gift stores, Costco, Walmart, and online sales, for their books. The market is often determined by the book itself. Business books, for example, are frequently sold through seminars presented by the author - even if only 20 copies.

Advertising popular culture titles over the Internet is another alternate market for ECW. Currently, ECW is producing a new title on the television show Lost. Viewers who do not understand what is going on in the show often turn to the Internet for answers, so ECW has decided to advertise online. That way, on one of the Lost websites, viewers will be presented with "everything that you want to know about Lost explained in this book: Finding Lost: The Unofficial Guide." This often results in orders for the book. "Those people probably don't even go into bookstores. But they will order online or go to amazon.com or barnesandnoble.com. Bookstores, yes, but you have to figure out where else you can find the actual people. What you're doing is you're saying that I know there is a market for this book because 10 million people watch Lost every week. How do I get to those people? Either you advertise on the show, which is pricey, or you find somewhere else to advertise" (David). 


\section{Corporate and Custom Publishing}

Reallocating its skills in researching, editing, and design yet again, ECW has turned to the corporate and custom publishing markets for alternative revenue sources. Large companies or institutions often publish books to commemorate a significant anniversary. These books are created for employees, retirees, alumni, and clients, to say "this is who we are and we're pretty proud of ourselves." Large institutions want a top-quality product and have the financial means to pay for it. Corporate publishing also eliminates the need for marketing, since the company will buy all the copies published to give away.

Another way to derive additional income from corporate publishing is to sell the book as a trade title. A book that ECW is currently preparing in celebration of the fortieth anniversary of York University's Schulich School of Business may not have trade potential. But a book commemorating the one hundred and thirty-fifth anniversary of the Toronto Argonauts - ECW is still negotiating this title - may have the potential for additional trade sales.

\section{Rights}

One important result of globalization is that Canadian publishers, in order to succeed in foreign markets, are publishing books specifically for those markets, particularly the U.S., Australia, New Zealand, and Britain. David suggests, in fact, that the efforts of Canadian publishers "are being sucked away from doing, say, a Corner Gas book and instead doing an $X$-Files book because the market is bigger and you can make some money on the book. The 
government has been very encouraging of publishers to increase their export sales and export sales have jumped dramatically. But if you take a look at the actual books that have sold as exports, they have not been true Canadian books" (David). Ironically, the revenues of Canadian-owned publishers may be increasing, but not necessarily due to increased publication of Canadian books for Canadian readers.

\section{Looking Forward: Globalization and Canadian Identity}

In spite of all the challenges that ECW faces, the Press continues to adapt and survive. While David believes that publishers need to be "nimble and aggressive, willing to come up with different ways to make money," he also believes that a lot of Canadian owned publishing companies will not survive. Those that have survived are not growing. For David, "holding the line is the new up" or "flat is the new up," referring to the lack of growth potential in the industry: "I think that we're kind of like radio when television came out, we're there, people like to read, but it's not a growth market" (David).

David admits that maintaining a Canadian identity is important for ECW, but it is a difficult undertaking. While David believes fiction authors are easier to identify as Canadian, non-fiction authors could just as easily be American or British. As a Canadian publishing company, ECW writes Canadian books on Canadian subjects. Referencing former Minister of Culture Shelia Copps, David affirms the importance of telling Canadian stories to Canadians: "Whether it's 
biography or social commentary or poetry or drama, that's what we need.

Otherwise, two seconds later we'll be the fifty-first state" (David).

For ECW Press, the positive result of globalization is that it has forced Canadian publishers to increase their market outside of Canada: "See that Muddy Waters book that we did? That book was written by a Canadian. So is that a good thing for Canadian culture - that a Muddy Waters book was written by a Canadian author? It's an interesting question. Couldn't hurt, I guess. . . . Take a look at the Frank Zappa books written by a Canadian. Is that a valuable thing to do? Well, it's valuable to the author who can walk down the street and talk to his publisher. Overall, we're Canadian, so we publish Canadian books, but we can't afford to do it as our sole activity" (David). 


\section{Chapter Two: McClelland \& Stewart and Douglas Gibson}

Over 20 years ago, in 1986, Douglas Gibson was wooed away from the Macmillan Company of Canada to join McClelland \& Stewart as an editor. Two years later, in September 1988, Avie Bennett, then chairman and president of the company, asked Gibson to become publisher of M\&S, after the departure of then publisher Adrienne Clarkson. Gibson agreed and remained as publisher of the company until 2000 , when Bennett gifted his portion of M\&S to the University of Toronto. Between 2000 and 2004, Gibson served as president and publisher of the company. In 2004, he returned to his original and best-loved position at M\&S - editor of his own imprint, "Douglas Gibson Books." His vast experience in publishing affords Gibson invaluable insight into the conditions of book publishing in Canada.

\section{History of McClelland \& Stewart}

Gibson describes the beginning of M\&S: it started in "the usual way for Canadian publishing companies" (Gibson). A couple of book sales people by the names of John McClelland and Frederick Goodchild got together and decided to start a publishing company. In 1906, however, this meant a book distribution company because almost all the publishing was done exclusively in the United Kingdom or the United States. The publishers in the U.K. and the U.S. found agents to represent them in countries such as Canada. Sales people from these agencies would then go across the country selling foreign publications.

One of the most significant moments in the history of M\&S was the decision by McClelland and Goodchild in the 1920s to move from being 
exclusively distributors of books to becoming books publishers. During the forties, the Second World War made it a tough time to publish books because paper was in short supply. The next significant change came in 1952 when Jack McClelland took over from his father: "Jack was quite young and determined to be a real publisher and he actually cut back on the number of U.S. and U.K. companies that McClelland and Stewart distributed in the early '60s" (Gibson). McClelland spent his time scouting Canadian authors whose careers he could develop, new voices such as Margaret Laurence, Mordecai Richler, and Al Purdy. In 1963, Jack McClelland dropped "23 of its 28 agency lines" (MacSkimming 130), making McClelland and Stewart almost exclusively a publisher of Canadian books. In 2000, M\&S "shed all its agencies to a new company, Stewart House"1 (MacSkimming 397). Today, McClelland \& Stewart is exclusively a publishing company and no longer distributes books published outside of Canada.

"The main roadblock is how hard it is to make a living by publishing Canadian books" (Gibson). It is easier to be a Canadian distributor than it is to be a Canadian publisher. In distribution, foreign publishers take all the risks. For M\&S however, the real roadblocks to success have been financial difficulties. In the early 1970s, McClelland had successfully published more and more books with bigger and bigger budgets. By 1981 and 1982, however, M\&S was in serious financial trouble. "The company was helped out by a loan from the Ontario government and for a number of years that sort of continued, until there

\footnotetext{
${ }^{1}$ Stewart House, owned by a former M\&S employee, sought bankruptcy protection in 2003
} 
were real crises in the ' 80 s and eventually Avie Bennett bought the company in '86"' (Gibson).

Bennett had been a successful real estate developer and it was during a brief stint as a director of $M \& S$ that he had become fascinated by the problems facing a cultural industry like publishing and the challenge of how to keep the business profitable. Bennett grew M\&S for 14 years, often investing his own funds into the company. At 72 , he decided to sell M\&S and arranged a shared venture between the University of Toronto and Random House Canada. Bennett donated 75 per cent of M\&S to the University, making it the majority owner, with five of the seven seats on the board. Random House, the world's most powerful multinational publisher, would own 25 per cent and have "two seats on the board for its one-quarter stake (the maximum a foreign investor could own if the company were to remain eligible for grants)" (MacSkimming 375). Random House would also take responsibility for sales, distribution, accounting, and financial management, which further complicated the landscape of Canadian publishing.

\section{Difficulties}

Echoing the difficulties cited by Jack David of the much smaller ECW Press, for Doug Gibson the biggest challenge facing all Canadian publishers is how to stay in business. Although M\&S has faced many of the same challenges as ECW Press, it has been adversely affected by specific difficulties. These include the infiltration of the Canadian market by foreign English-language books, 
distribution problems, advancing technology potentially replacing the traditional text, marketing books to Canadian readers, and issues pertaining to rights.

\section{Infiltration}

Doug Gibson notes that with more than 100,000 English-language books published world-wide each year, Canada is at the centre of all of these publications. Owing to a history of distributing English-language foreign books, Canada has created for itself the most competitive English-language book market in the world. Just about every book published in Britain is made available through Canadian agents, while very few of these same books make it into the U.S. Then, for geographic and economic reasons, just about every American book comes into Canada, although very few of them make it across the pond to the U.K. "So we're getting every U.K. book and every U.S. book and, into the middle of this, we have to try to launch our own Canadian authors" (Gibson). While this is wonderful for Canadian readers, "it is terribly tough competition for Canadian authors and publishers when you happen to share a world language with the main world publishing powers" (Gibson).

In addition to the saturation of the Canadian market by English-language books, each of Canada's many regions support different publishing houses, all competing for distribution in Canadian bookstores. While 244 of the 627 publishers in Canada are based in Ontario (http://www.omdc.on.ca/Page3652.aspx), there are dozens of small and mid-size publishers - Douglas \& Mclntyre in Vancouver, British Columbia, for example - 
scattered across other regions of Canada. The rest of the publishing market is occupied by multinationals, such as HarperCollins, Penguin, and the Random House group, which includes Doubleday and Knopf. Like ECW Press, M\&S faces stiff competition, despite the fact that Random House owns 25 per cent of the company. Random House's group of companies has massive subsidization of its Canadian publishing program through enormous sales in Canada of books like The DiVinci Code and other bestsellers.

In spite of the stress added by an overabundance of English-language books and the proliferation of Canadian publishing companies, Gibson feels that the book retail environment in Canada is by far the most significant negative factor. "We have one massive chain, by that I mean Indigo-Chapters, which occupies 60 to 70 per cent of the market. And there is nowhere else in the world where you get that" (Gibson). Compared to the U.K. market, where there is similar criticism of W.H. Smith, which only occupies 25 per cent of the market, Indigo-Chapters remains a destructive force for publishers. "Demonstrably, too, the chain is not terrifically efficient and not terrifically successful. If they were really great at what they do, that would be one thing, but that's not the case" (Gibson).

\section{Distribution}

Canadian publishers also face problems with distribution. For 20 years, Gibson has been giving lectures, in which he derides book distribution in Canada as "insane"; he calls it the "teamsters' distribution system." In an effort to explain 
himself, Gibson describes the journey of a book from printer to bookstore. "We publish a major book and we print it in the middle of Manitoba at Friesens ${ }^{2}$, the largest of the Canadian printers, and each book weighs, let's say, two pounds, a fine, big, healthy hardcover book. And it's stuck in cardboard cartons, it's put on a truck, and it's trucked to the publisher's warehouse, near Toronto, right? All the way from Manitoba to near Toronto. A bookseller in Victoria, B.C. says, 'yes, I want ten copies of that book.' So our ten books go by truck across the country to Victoria. And they don't sell, right? So guess what happens? The bookseller is entitled to return them. He puts them in another cardboard box and they go in another truck all the way to the warehouse in Toronto! But guess what? The book is doing very well on the East Coast. It's John Crosby's memoirs, so, they want it in Newfoundland. The same books go on a truck to St. John's and they sit there for a bit, but they don't sell. Soon they go back to the warehouse in Toronto. And this happens every day of the year. This is insane; we all agree. So I have said that we have to stop this nonsense, which is good for no one but the teamsters and the trucking companies" (Gibson).

Gibson believes there must be a better way. He recommends something he calls the "Roman System." Similar to the rewriting of a scroll, Gibson describes a bookstore that would have the equivalent of a modern-day printing press in the back. Customers could request books by looking at display copies and the bookseller could print the books right in the store, eliminating the need to ship the books across the country. To put this idea into perspective, Gibson recalls another technological advance that took place not that long ago. "Thirty

\footnotetext{
${ }^{2}$ Friesens, established in 1907, in Altona, Manitoba
} 
years ago when an author delivered a manuscript to a publisher, the publisher marked it up, then took it to a printer who re-typed the whole thing. That was what a typesetter did, re-typed the whole thing. To go from that, to today's author as his or her own typesetter, was a huge technological advance" (Gibson). Unfortunately, technology has not yet been employed to advance and refine the distribution and selling of books across Canada.

\section{Technology}

While advancing technology may help solve problems associated with distribution, larger issues are beginning to surface that reach beyond Canada to the global book industry. Gibson makes reference to an article by Kevin Kelly, entitled "Scan This Book!", that appeared in the New York Times Magazine in April 2006. Kelly suggests that we have to get away from the idea of the book as an individual, material object, accept that the book will circulate as information in a variety of forms, and expect that people will be searching for and finding books online.

Turning inked letters into electronic dots that can be read on a screen is simply the first essential step in creating this new library. The real magic will come in the second act, as each word in each book is cross-linked, clustered, cited, extracted, indexed, analyzed, annotated, remixed, reassembled and woven deeper into the culture than ever before. In the new world of books, every bit informs another; every page reads all the other pages (Kelly http://www.nytimes.com/2006/05/14/magazine/14publishing.html?ei=5 090\&en $=c 07443 \mathrm{~d} 368771 \mathrm{bb} 8 \& \mathrm{ex}=1305259200$ \& pagewanted=all). 
Jumping from one on-line book to another creates a whole new way of reading. As they read, individuals draw from one book, are led to another book, cross reference to the next book, and so on.

This major change in reading practices has implications for publishers who must adapt to a new form of reading and make it profitable. Kelly makes the point that the battles that occur in the music industry over copyright, fair use, and photocopying are really in defence of the business model. The business model for the music industry dictates that for every piece of music sold the money flows a certain way and the author receives a percentage of the sale. When the traditional model no longer holds, those affected find it difficult to adjust to a different kind of business model. Although Kelly cannot predict the future, he recognizes that the transformation to digital reading will be a long process.

The digitization of books raises important issues for the book industry. In his article "Google Print vs. Onsite Collections," Thomas Mann warns against Google or a Google-type keyword searches as a replacement for library-based research - even though Google Print might offer the ability to search texts quickly and easily. Unlike the subject-classification of a library shelf, the "relevance ranking" search software employed by Google and Google Print destroys the possibility of "systematic subject searching." The inability to build connections among multiple sets of words with the same idea, for example, will make some searches impossible for researchers. 
Mann uses the example of a graduate student researching Paul Valery, the French symbolist poet, and his connection to the Dreyfus affair of the 1890s. The student hears offhandedly that Valery had signed a petition on the issue.

The ARTFL database of digitzed French texts did not help; neither did biographies, several subscription databases, or two massive bibliographies on Valery. Finally, I had to go into the Library of Congress stacks, where there are 186 volumes on six shelves in the classes DC354-354.9 ("Dreyfus affair"). I was looking for one book of primary sources that I located in the online catalog with the subject heading "Dreyfus, Alfred, 1859-1935-Trails, litigation, etc.-Sources"; however it did not include the Valery petition. But on the shelf above it I noticed another book, which, it turned out, did indeed have the necessary information (Mann 45).

Mann goes on to explain that the source he discovered also contained additional information that the student had not requested about one of Valery's close friends. Mann suggests that if these texts had not been shelved together, if they were in storage boxes in a remote warehouse, or worse, digitized and keyword searchable, then this important information would not have been found. In fact, "classified shelving enables researchers to recognise sources whose keywords they could never specify in advance" (Mann 45).

\section{Marketing}

Although effective marketing is difficult for small companies with limited funds - such as ECW Press - it is also difficult for larger companies, like M\&S, that have few market venues for their books. The Canadian radio, television, and print media are devoting less and less broadcast time and column space to book reviews and book related content. Moreover, the print media itself - literary 
magazines and newspapers - is subject to the same difficulties facing Canadian publishing companies.

CBC television and, more significantly $\mathrm{CBC}$ radio - in particular, Peter Gzowski, the host of "Morningside" - were traditionally thriving venues that promoted an awareness of and appreciation for Canadian authors and their books. "Since Peter Gzowski's death in 2002, the talk of Canadian books on the radio has just stopped. Shelagh Rogers and one or two other people do their best, but we've lost that sense of communal conversation on $\mathrm{CBC}$ radio, with Canadian books as the main topic of conversation" (Gibson). In fact, a broadcast ruling by the Canadian Radio-Television and Telecommunications Commission (CRTC) in the mid-nineties loosened the restrictions on how much time must be devoted to talk radio, making more time for music. Gibson reflects that "overnight all of the interesting discussion shows that welcomed authors were gone" (Gibson).

Print media also devotes minimal space to promoting Canadian books. Few print publications, other than the Globe and Mail, make a concerted effort to include Canadian material. Newspapers often opt to print a book review of an American book from a news wire instead of commissioning an original review of a Canadian text. Gibson refers to another publishing professional at Penguin who estimates that since 2000 the number of venues available for promoting Canadian books has been cut by at least 25 per cent. "It's a constant uphill struggle to simply let the Canadian public know about the existence of new 
Canadian books. And it always has been a struggle, but l've seen it get much, much worse just in the last few years" (Gibson).

Most devastating to publishers, perhaps, is the fact that the Canadian magazine industry has fallen on hard times in the last decade. With increased competition from American magazines, funding cuts by the federal and provincial governments, and dwindling interest from advertisers, many magazines have collapsed. Moreover, the appearance of new general interest Canadian magazines is not common in this conflicted and largely unprofitable market.

Historically, Canadian magazines were an excellent training ground for young Canadian writers. Young authors could write stories for magazines that would be longer than pieces in newspapers, with an increased emphasis on research. "Magazines gave us a sort of 'farm league' where we could see promising writers. We'd say 'hey this is a really good piece' and the piece could be 7000 words long and you think, 'well, just nine more of these and you have a book'" (Gibson). With the recent suspension of publication of the 118-year-old Saturday Night magazine due to financial difficulties, another venue for the training and marketing of young writers has disappeared. The difficulty now is finding publishers of long thoughtful essays - although magazine's such as Walrus are attempting to address this need. Walrus and other newspapers and magazines have tried to address the need for training young writers through paid and unpaid internship programs with Walrus' paid internships built into their ongoing plan. 
At the corporate level, M\&S no longer conducts any marketing in-house.

Quill \& Quire recently reported that the entire M\&S marketing department - three employees - had been dissolved, and that M\&S now depends upon the Random House marketing department for all its marketing needs. As president and publisher Doug Pepper explained, the "plan for M\&S to use Random House's marketing services was 'something that has been in the works,' . . . 'It's also a way to lower our overhead,"' (Rowe http://www.quillandquire.com/news/article.cfm?article_id=7091). M\&S now takes advantage of many of Random House's services, such as sales and accounting.

\section{Strategic Initiatives}

Like ECW Press, M\&S also has plans for remaining competitive and successful in the future. Unlike ECW, however, its options are somewhat limited since M\&S receives only some of its revenue from foreign book sales. M\&S is still struggling to adapt to a changing market for books and finding the means to allocate more funds to its publishing program.

\section{Rights}

Selling rights abroad, as in the case of ECW Press, can be a lucrative strategy for publishers. This is not always possible, however, as in the case of M\&S. While M\&S acts as agent for many authors, including Madeline Thien whose book Simple Recipes is selling worldwide, it does not act as agent for many of its more commercially successful authors, such as Michael Ondaatje 
and Margaret Atwood. Rather, each of these author's agents offers M\&S Canadian rights only and negotiates separate contracts for American rights with an American publisher, British rights with a British publisher, and separate contracts with other interested publishers. So while it does make strategic and economic sense for M\&S to act as agent for all its authors, this arrangement is not always possible.

\section{Publishing Fewer Books}

Another way in which M\&S is trying to change and adapt is by publishing slightly fewer books each year. Focusing on fewer titles is a way in which M\&S hopes to do better with the titles that it does publish. This is not just a trend for M\&S but a move that many publishers are making. As a result of large-scale returns and the narrowing of the retail market, what and how much a publisher will issue is increasingly restricted. "Canadian publishers may produce 20 per cent fewer Canadian titles in the spring and fall as a result of a financial squeeze caused by heavy book returns - instead of payment - from retailer Chapters Inc." ("More"). While it is fiscally prudent for companies like M\&S to take this precaution, it could have a significant impact on Canadian culture. "The cuts could have a long term detrimental effect on Canadian culture if publishers stop taking risks on less commercially marketable books, a senior Canadian Council warned Ottawa" ("More"). 
Policy

One of the most important funding bodies that supports M\&S is the Canada Council for the Arts which helps develop writers' careers and sustain the publishers that issue their work. As a granting body, the Canada Council can provide additional income for the Canadian publishers. These grants can help to level the playing field with a multinational publishing company that would likely derive their additional income through sales of American bestsellers in Canada.

\section{Looking Forward: Globalization and Canadian Identity}

Although M\&S does not always benefit financially from its internationally successful titles, the company is nonetheless proud to publish remarkable books that are distinctively Canadian. Gibson acknowledges that "it would be a mistake for a Canadian publisher to deliberately smooth off all their Canadian edges because that would take away what is distinctive about the Canadian publisher, just as Canadian film shouldn't hide why it looks like a Canadian film" (Gibson). In his time as publisher at M\&S, Gibson tried to remain conscious of the company's title as "The Canadian Publisher." By remaining committed to publishing excellent Canadian books, quality followed. Proudly, Gibson recollects a year in which M\&S published a book from every province and territory in Canada. "To give Canadians in every part of the country a chance to learn about each other and to learn to speak to each other was terrific - and then the rest of the world followed. That's good too" (Gibson). 
Giving Canadians a chance to speak to each other through their writing and inviting the attention of the world has resulted in some of M\&S's most internationally successful books. Gibson remarks that if writing were an Olympic sport then Canadian men and women would be on the podium all the time. "It's not because we're nice guys that our people keep winning international prizes; it's because they deserve to win international prizes" (Gibson). By remaining largely uninterested in its books' global significance, M\&S has produced Canadian books for Canadians that today are appreciated globally, reinforcing Canadian identity on a broad scale. "This is not open to debate: our writers are as good as you get in the world" (Gibson). 


\section{Chapter Three: Random House of Canada / Knopf Canada and Michael Schellenberg}

Michael Schellenberg's first job was "Canadianizing" American textbooks at John Wiley and Son until 1993; subsequently, he moved to Penguin Canada where he remained from 1993 to 2003. Since 2003, however, Schellenberg has been senior editor with one of Random House's major imprints, Knopf Canada. When Random House and Doubleday merged in 1998, Random House of Canada controlled over 25 per cent of the Canadian publishing market with such imprints as Knopf Canada, Vintage Canada, Bantam, Dell, Seal, and Anchor (MacSkimming 368). Since the merger, and despite the closure of several Canadian publishers, Random House's control of the market continues to grow, aided by its partial ownership of McClelland \& Stewart.

\section{History of Knopf Canada}

Knopf was originally a large American publishing company that was started in 1915 New York by Alfred Knopf; it merged with Random House in 1960. Knopf began its Canadian publishing arm in 1991, headed by current Random House of Canada publisher and vice-president Louise Dennys. At the time, Dennys was publisher at Lester \& Orpen Dennys and had issued many great Canadian and international writers, including Mordecai Richler, Rudy Wiebe, Graham Greene, and Jeanette Winterson. Knopf Canada was first based in Dennys's Spadina Gardens apartment; a year and a half later, Random House Canada moved its headquarters from Mississauga to downtown Toronto. 
Knopf has now been in Canada for 15 years and has issued many major Canadian works. Its New Face of Fiction (NFOF) program supports first-time Canadian authors and, in its debut year, Knopf published Ann-Marie MacDonald's first novel, Fall on Your Knees, which went on to sell over 200,000 copies. Also published under the NFOF banner are other success stories, such as Gail Anderson-Dargatz's The Cure for Death by Lightning, Dionne Brand's In Another Place, Not Here, and Erika de Vasconcelos's My Darling Dead Ones.

Despite its American origin, over the last 15 years Knopf has issued important Canadian works and in 1997 received the Publisher of the Year Award from the Canadian Booksellers Association, an honour that recognized "the excellence of Knopf Canada's publishing programme and its outstanding contribution to Canadian culture" (http://www.randomhouse.ca/about/knopf.html).

The founder of Knopf, Alfred Knopf, also had a close tie with Canadian publishing. Jack McClelland of McClelland \& Stewart was like a surrogate son to Knopf; McClelland often visited Knopf in New York to learn about the business of publishing. McClelland hoped that one day M\&S would become "the Canadian Knopf" (MacSkimming 127). More than half a century later, the relationship between M\&S and Knopf is closer than McClelland could ever have envisioned: both companies are partially owned by the multinational Random House.

\section{Difficulties}

Owing to its significant presence in the Canadian marketplace, Random House and Knopf do not face the same difficulties confronting Canadian-owned 
publishers. In fact, Random House and the other two American multinational publishers in Canada, Penguin and HarperCollins, are often cited as the major problem facing Canadian-owned publishing. "Foreign-controlled book publishers represent only $4 \%$ of the publishers in Canada, but earn $49 \%$ of pre-tax profits, and employ one third of full-time employees" (http://www.omdc.on.ca/Page3652.aspx ). Their competitive presence in the Canadian book industry has been devastating for many Canadian-owned publishers. However, Random House and the other multinationals also contribute greatly to Canadian literary culture by publishing dozens of Canadian books a year. Moreover, subsidized by American sales, Random House has the ability to promote its books throughout Canada and abroad.

\section{Independent Bookstores}

Like ECW Press and M\&S, Schellenberg sees a lack of independent bookstores where there was once a healthy retail industry. "There are some very good independent bookstores but I wish there were more. Since the books we tend to publish tend to be favoured by independent booksellers" (Schellenberg). Unlike ECW and M\&S, however, Schellenberg does not fault Chapters-Indigo or comment on its dominance of the book retail market. In fact, Schellenberg is satisfied with the chain. "Indigo under Heather Reisman has been fantastic. It supports our books, and I can't really complain about that" (Schellenberg). 
The Role of Non-Canadian Publishers in Canada

A particular difficulty for Knopf is its ineligibility for Canadian grants since its owner, Random House, is considered a foreign publisher. While Knopf and other Random House imprints produce dozens of Canadian titles each year, they are unable to receive funding from the federal and provincial governments because they are foreign-owned imprints. In order to be eligible for federal and provincial grants, a publishing company must be 75 per cent Canadian owned, and for this reason Random House has been limited to a 25 per cent stake in M\&S. Although in principal Schellenberg understands why multinationals like Random House are not eligible for Canadian grants, he opposes the negative representation of multinationals by the Canadian publishing community. "I think there's not enough recognition given to the depth and breadth of the Canadian books that are being published by the larger international publishers within Canada. I think we're often seen as the big bad guys, but I think we serve an important function by allowing Canadian writers to make a living by writing" (Schellenberg).

\section{Strategic Initiatives}

Schellenberg believes that the publishing industry in Canada is currently doing very well, although he is aware that Canadian publishers may disagree with this view. Schellenberg notes that "Random House has had a particularly good run of it. I think if you talk to anyone else they might be a little less happy but Canadian publishing is actually quite healthy right now" (Schellenberg). In the 
case of Knopf, Schellenberg attributes its good fortune, in large part, to the strategy it continues to follow: publish the best books, adapt to the market, and lead publishing trends.

\section{Quality Publishing}

Schellenberg considers Knopf's ability to publish books that are editorially driven an important strategy for its continuing success. "Knopf is an editorially driven house, which is becoming more and more of a rarity in publishing. We are not market driven. We are driven editorially, but our editorial books are quite successful so we are lucky that way" (Schellenberg). An ability to adapt to the market while being editorially driven is another of Knopf's strengths, which Schellenberg attributes to Random House management.

\section{Publishing Trends}

As trendsetters instead of followers, Random House and Knopf Canada have published a number of successful books. Schellenberg points to a couple of instances where Random House and Knopf have led the trend. One example is Carl Honoré's In Praise of Slow, published in 2004. This book - mainly about different aspects of the slow movement, including slow food, slow health, and slow and mindful parenting - quickly became a bestseller. Since then, other publishers have issued several books on the slow movement. Another example is Naomi Klein's No Logo. "No Logo definitely changed the way a whole generation thinks about consumerism, and is probably the best example of 
trendsetting. In Praise of Slow would be a more recent example of this strategy" (Schellenberg).

\section{Looking Forward: Globalization and Canadian Identity}

It is true that many Canadian publishers see multinational publishers like Random House of Canada as a negative force in the Canadian book industry, and Schellenberg admits that he is more positive than most about the future of Canadian publishing. "We publish international writers but focus on our Canadian-born or Canadian-bred writers. I think Canada's great strength as a nation is its multicultural nature and that's what's so great about its writing. Knopf attempts to publish writers from many different cultures. We look for the most interesting voices, and right now Canadian writers are producing some of the most interesting books" (Schellenberg).

Schellenberg indicates that globalization has made publishing more difficult in several ways, but concludes that Canada is perfectly positioned to succeed and retain its identity globally. "Canada is quite adaptable in a global market because its nature is that of a polyglot, opposed to one race or one dominant view. Canada contains so many multitudes of voices and people's experiences that I think it reflects the world in a way. In that sense, Canada is perfectly suited to globalization" (Schellenberg). 


\section{Conclusion}

In the past two decades, the Canadian publishing industry has faced perilous times in an already troubled market sector. In addition to the problems specific to the Canadian publishing industry - federal and provincial funding cuts to the industry; the monopoly of the book retail market by the chain outlet Chapters-Indigo, the difficulty and expense of book distribution within Canada, competition from multinational publishing companies, the lack and expense of traditional marketing opportunities - the growing global market for books presents further difficulties for an industry that is struggling to retain its "Canadian" focus. This study has considered the recent impact, both positive and negative, of globalization on the Canadian book industry, with a specific focus on publishers as the central figures in this industry.

My subjects, ECW Press, McClelland \& Stewart, and Knopf Canada, an imprint of Random House of Canada, have offered valuable insights into the difficulties presently affecting the industry. These insights allow me to draw several conclusions, most notably, that the larger the publishing house, the less troubled it is by market conditions. Although I initially hypothesized that globalization would be a negative influence on Canadian publishing, it has proven to be a positive and necessary force for the survival of all three of my subjects - in particular ECW Press, which is most affected by market changes. Moreover, the question of whether it is possible to maintain a Canadian identity in a global market is not especially pressing, since many of the Canadian books currently in print would not have been produced without the global market 
subsidizing the industry. The global market offers an opportunity for Canadian books to receive both national and international recognition, win national and international awards, and subsidize the publication of more Canadian books thereby reinforcing the cultural identity of Canada, both at home and internationally.

Not only is it possible to remain Canadian within a global market, but I believe that it has become increasingly difficult to remain Canadian without a global market. A new kind of Canadian identity - created from the combination of diverse nationalities and cultures that incorporate the Canadian experience alongside a global presence and understanding - is being developed through the ability to publish more Canadian books. The Canadian publishing industry is rife with problems - inadequate policies and competition laws, an inefficient book retail market and distribution, and poor marketing - and yet many Canadian publishers prevail.

However, the global market is not without its own problems. While Canadian publishing does prevail, it does without many of the Canadian publishers that existed decade ago that have either gone bankrupt or been bought by larger American and Canadian firms. Even as I complete this study another issue associated with globalization is faced by my subject ECW Press. In the January/February 2007 Quill \& Quire, Jack David is quoted as saying that EWC Press lost more than $\$ 500,000$ since 2003 in exchange rate loses due to the rising Canadian dollar and sales in the United States. Although currency fluctuation is a risk for any company doing business outside of Canada, this is 
especially worrying for Canadian publishing since the industry is already threatened within Canada itself.

While the global market is not the only influence that keeps Canadian publishing profitable and despite many of the issues associated with globalization, I am certain that without access to this market, the landscape of Canadian publishing would be much less rich than it is today. And while the "Canadian" focus may have become somewhat diluted in the global market, I believe there is value in the attempt to retain this focus, both financially and culturally. Indeed, the attempt to retain a Canadian focus, despite the numerous difficulties threatening the health of the industry, has been articulated as a priority by all three publishing companies considered in this study. The global market is helping to improve the health of the Canadian publishing industry, and despite the many negative issues associated with globalization, as more Canadian books and authors are appreciated globally, the more likely it is that future generations of Canadian authors will have the opportunity to share their stories with Canada and the rest of the world. 


\section{Appendix A: Interview Questions}

History of the Company

1) How did the company start?

2) How long has the company been in business?

3) Has it undergone many changes in its history?

4) What are some of the significant milestones or roadblocks that the company has faced in its history?

5) How has this history led to the company's current role in the industry?

History of the Individual

1) How did you get started in the publishing industry?

2) List and expand upon your roles in the industry prior to your current position.

3) Compare your current position to others that you have held in the publishing industry.

4) What are your responsibilities in your current position?

The Publishing Industry

1) How would you describe the current "shape" of the publishing industry in Canada?

2) What are the dominant problems currently affecting the health of the industry, both in Canada and worldwide?
a. Bookstores
b. Distribution
c. Marketing
d. Writing
e. Policy Issues
f. Language Issues

3) Please comment further on the issues that affect Canada specifically, and explain why these problems are specific to Canada. (i.e., how is the Canadian publishing industry unique?)

Canadian Publishing in a Global Market

1) Does the increasingly global market for publishing affect the Canadian publishing industry positively or negatively? Please explain. Who succeeds? Who suffers? 
2) Please comment on cultural policy initiatives - both recent and past initiatives - by the federal government and, to a lesser extent, the Ontario government. Have they:

a. Helped the industry?

b. Harmed the industry?

\section{The Future of Publishing in Canada}

1) How has your company survived in the publishing industry, both in Canada and worldwide?

2) What are some strategic initiatives that your company might adopt in:

a. The next year?

b. The next five years?

c. The next ten years?

3) How do you think other companies plan to adapt to the changing climate of the industry?

4) What does the future hold for Canadian publishing in today's global market?

5) Is it possible for publishers to maintain a Canadian identity in today's global market?

6) Has globalization been a positive change for the Canadian publishing industry? 


\section{Works Cited}

Canadian Heritage website. 30 Mar. 2005.

$<$ http://www.pch.gc.ca/progs/ac-ca/pol/livre-book/index e.cfm>

Crawley, Devin. "Ontario Triples Tax Credit for Publishing New Writers, Extends Eligibility." Quill \& Quire 13 Feb. 2001.

<http://www.quillandquire.com/news/article.cfm?article_id=4069>

David, Jack. Personal interview. 3 Apr. 2006.

Gibson, Douglas. Telephone interview. 15 May 2006.

Industry Profile: Book Publishing website. 15 Dec. 2006.

$<$ http://www.omdc.on.ca/Page3652.aspx>

Kelly, Kevin. "Scan This Book!" New York Times Magazine 14 May 2006.

<http://www.nytimes.com/2006/05/14/magazine/14publishing.html?ei=509 $0 \&$ en $=$ c07443d $368771 \mathrm{bb} 8 \&$ ex $=1305259200 \&$ pagewanted $=$ all $>$

Lahey, Anita. "Advances Climbing in Heated Market." Quill \& Quire 1 Oct. 1998. $<$ http://www.quillandquire.com/news/article.cfm?article id=1183>

Lorinc, John. "Culture vs. Commerce." Quill \& Quire Dec. 2001.

$<$ http://www.quillandquire.com/features/article.cfm?article id=2228>

MacSkimming, Roy. The Perilous Trade: Publishing Canada's Writers. Toronto: McClelland \& Stewart, 2003.

Mann, Thomas. "Google Print vs. Onsite Collections." American Libraries 36.7 (2005): 45-47.

Milliot, Jim. "Marginal Profit Improvement in '05." Publisher's Weekly 21 Aug. 2006.

$<$ http://www.publishersweekly.com/article/CA6364168.html?text=penguin+ and+profit>

"More Book Returns Means Fewer Canadian Books, Say Publishers." Canadian Press Newswire 21 Mar. 2001.

Ontario Ministry of Culture website. 30 Mar. 2005.

$<$ http://www.culture.gov.on.ca/english/culdiv/cultind/bookpub.htm>

Random House of Canada website. 5 Dec. 2006.

$<$ http://www.randomhouse.ca/about/knopf.html> 
Rowe, Dan. "M\&S Moves Marketing to Random House, Lays Off Three." Quill \& Quire 10 Mar. 2006.

$<\mathrm{http}: / / \mathrm{www}$.quillandquire.com/news/article.cfm?article_id=7091>

Schellenberg, Michael. Telephone interview. 22 May 2006.

Stoffman, Judy. "Bankruptcy: Litchmans's Sombre Final Chapter." Toronto Star 31 Mar. 2000: News 1.

Teitel, Murray. "These Booksellers Truly Love Books." Toronto Star 19 Nov. 1999: News 1.

Yanofsky, Joel. "Really New Faces." Quill \& Quire June 2002.

$<$ http://www.quillandquire.com/features/article.cfm?article id=2313> 